\title{
DISTRIBUTION AND DIVERSITY OF FORAMINIFERA IN THE NORTHWEST OF SARAWAK OFFSHORE WATERS, MALAYSIA
}

\author{
WAN NUR SYARAH WAN MUHAMED SABRI ${ }^{1}$, OMAR ABDULA RAHMAN ABDUL MANAF ${ }^{2}$ AND \\ FATIN IZZATI MINHAT ${ }^{3 *}$
}

\author{
${ }^{1,2,3}$ Pusat Pengajian Sains Marin dan Sekitaran, Universiti Malaysia Terengganu, 21030 Kuala Nerus, \\ Terengganu. \\ ${ }^{3}$ Institut Oseonografi dan Sekitaran, Universiti Malaysia Terengganu, 21030 Kuala Nerus, Terengganu.
}

\section{*Corresponding author: fatinminhat@umt.edu.my}

\begin{abstract}
A study on distribution and diversity of benthic foraminifera in surface sediments was carried out in Northwestern Sarawak waters, Malaysia. The range of water depth at the study site was between 43 $\mathrm{m}$ and $71 \mathrm{~m}$. A total of seven sediment samples were taken for this study. As a result, 11 genera were identified from a total of 1,222 individuals of foraminifera. 200 individuals were picked out from each sample. The 11 genera that were identified from the study site included Heterolepa spp., Textularia spp., Quinqueloculina spp., Operculina spp. Pseudorotalia spp., Amphistegina spp., Cylindroclavulina spp., Elphidium spp., Ammobaculites spp., Asterorotalia spp. and Bolivina spp.. The common genera found in the sediments of the study areas were Heterolepa, Textularia, Quincoloculina, Operculina and Pseudorotalia. The highest and lowest values of Fisher alpha and Shannon-Wiener indices were shown at Station C287 and Station B482 respectively. The highest value of Fisher alpha was 3.23 and the lowest value was 1.97. The highest and lowest values of Shannon-Wiener were 2.30 and 1.91. The highest index value of diversity was 3.23 at depth $67.76 \mathrm{~m}$ and the lowest value was 1.53 at depth $45.54 \mathrm{~m}$ and $68.45 \mathrm{~m}$. From this study, depth is not the main factor that influences the diversity of benthic foraminiferal in northwestern Sarawak waters.
\end{abstract}

Keywords: benthic foraminifera, Sarawak waters, species diversity.

\section{Introduction}

Foraminifera are useful indicators of the paleoenvironmental condition as they hold an evolutionary history that extend back to the Cambrian (Debenay, 2012). The classifications of the tests or shells are determined by the characteristics of the test wall composition and the arrangement of the chambers. The basic wall of the foraminifera is mostly built from organic matter such as sediment and calcium carbonate. Foraminifera can be divided into two groups, which are agglutinated and calcareous. The test of the agglutinated is mostly built from foreign particles collected in the sediment and cemented together to form a shell. The calcareous test can be subdivided into three major groups, which are microgranular, porcelaneous and hyaline. Calcareous test is constructed together from a single crystal of calcite and the suborder carterina is believed to secrete spicules of calcite which are then cemented together to form the test (Debenay, 2012). Environmental parameters such as temperature, turbidity, depth, substrate, hydrodynamic energy and $\mathrm{pH}$ are often-interrelated to determine the occurrence of large benthic foraminifera (Mihaljevi et al., 2014).

In the observation of the distribution of the sediment, benthic foraminifera are commonly used to indicate the depth of deposition of the sediment and successful for the shallow parts of the continental margins (Zoochi, 1960). The most important measurable environmental parameter that can affect the distribution of foraminifera is depth but it can only affect it indirectly (Renema, 2002). In shallow-marine environments, habitat heterogeneity is typically facilitated through a range of tidal regimes and wave energy (Robert \& Ormand, 1987; Mihaljevic et al., 2014). Since foraminifera quickly respond to the temperature and environmental changes, they have been used to reconstruct paleoenvironmental conditions (Murray, 2006; Cosentino et al., 2017). As foraminifera are influenced by the bathymetry, physicochemical characteristics of sediment and water quality, their abundance and distribution can be used to interpret palaeoenvironmental conditions, palaeomonsoons, palaeotemperature, palaeodepth, tsunami, sediment transport and pollution profiles (Yahya et al., 2014). The resulting benthic foraminiferal distribution usually exhibits a zonation that roughly coincides with increasing water depth, but absolute depth and taxonomic composition of zonation vary from region to region (Hayward, 2010). The aims of this study are to document the distribution of foraminifera in Sarawak waters and to identify the dominant species of foraminifera in Sarawak waters.

\section{Study Area}

Kuching, Sarawak, has a tropical rainforest climate and receives the annual Southeast monsoon. The overall monthly mean temperature in Sarawak is about $27^{\circ} \mathrm{C}$ 
with small annual fluctuations of approximately $1.5-2{ }^{\circ} \mathrm{C}$ (Tangang et al., 2006). According to Ramzah \& Phil (2007), Kuching is situated in the most western of Sarawak, the area where the heaviest rainfall appears (Kanamori et al., 2013). The location of samples was near Teluk Datu, Kuching, Sarawak. The average depth at the study area was $55 \mathrm{~m}$.

\section{Methodology}

A total of eight sediment samples were collected by Jabatan Mineral dan Geologi (JMG) in August 2008. Samples were placed in air tight container and kept in archives at JMG warehouse.

\section{Sample Processing}

Sediment sub-samples were collected from the bulk samples kept in JMG warehouse and placed in zip-lock plastic bags. Then the sub-samples were carefully transferred to UMT laboratory for further analysis. In the laboratory, samples were soaked overnight to allow sediment to soften. The soaked samples were then wetwashed through $63 \mu \mathrm{m}$ sieve and the residue on the sieve was transferred onto weighing boats to be oven-dried ( $\mathrm{Li}$ et al., 2005) at $50^{\circ} \mathrm{C}$ for 1-2 days. The samples were then ready for sorting. For picking and sorting process, the samples were spread out on picking tray and fine artist brush (\#000) size was used to sort the specimens. The picking and sorting were carried out with the aid of stereo microscope. A total of 200 individual specimens of foraminifera were picked randomly and sorted from each sample. In samples with less 200 specimens, all specimens were picked (Culver et al., 2013). The specimens were placed onto a special micro paleontological slide that had been coated with special glue (Scott et al., 2012). The specimens that had been sorted were observed under Scanning Electron Microscopy (SEM) for detailed identification. Scanning microscope is particularly useful to observe a minute and solid specimen or complex surface topography of a bulk specimen with the dimension far less that optical limit (Honjo \& Okada, 1968). The foraminifera's specimens were covered with film of electro-conductive material with uniform thickness. Then the specimens were observed using the SEM. The identification of foraminifera was carried out based on Loeblich \& Tappan (1988) and Culver (1994). The software used to identify the distribution and diversity of the foraminifera was Primer version 6 (Clarke et al., 2006). This software was used to analyse the species diversity using fisher alpha $(\alpha)$, Shannon Index, Evenness Index and Dominant Index.

\section{Results}

A total of 11 benthic foraminiferal genera were identified in seven surface samples from northwestern Sarawak waters (Table 1). The benthic foraminifera were dominated by calcareous group mostly from hyaline group of test. Overall, Heterolepa spp. was the most abundant benthic foraminifera (18\%) with a total of 238 individuals collected from all samples. Meanwhile, the rare genus was identified as Asterorotalia spp. (3\%). The Textularia spp. from agglutinated group was the most common agglutinated representative that occurred in all samples with an average of 2 individuals per sample. Figure 1 and 2 show the SEM images of some foraminifera species collected from Sarawak's waters.

Table 1: The relative abundance of foraminiferal genera in seven surface samples.

\begin{tabular}{llllllllll}
\hline Samples & $\mathbf{4 5 0 4}$ & $\mathbf{A 6 5 1}$ & $\mathbf{A 6 7 4}$ & $\mathbf{B 4 5 7}$ & $\mathbf{B 4 8 2}$ & $\mathbf{B 4 6 9}$ & $\mathbf{C 2 8 7}$ & no. sp. & $\begin{array}{l}\text { Relative } \\
\text { Abundance (\%) }\end{array}$ \\
\hline Amphistegina & 36 & 0 & 37 & 20 & 0 & 0 & 0 & 93 & 8 \\
Textularia & 35 & 26 & 27 & 31 & 28 & 23 & 25 & 195 & 16 \\
Cylindroclavulina & 31 & 0 & 16 & 17 & 0 & 4 & 0 & 68 & 6 \\
Heterolepa & 16 & 48 & 17 & 57 & 34 & 33 & 33 & 238 & 19 \\
Operculina & 33 & 24 & 6 & 7 & 4 & 48 & 20 & 142 & 12 \\
Quinqueloculina & 21 & 20 & 15 & 11 & 30 & 45 & 27 & 169 & 14 \\
Elphidium & 10 & 6 & 4 & 7 & 4 & 10 & 6 & 47 & 4 \\
Ammobaculites & 0 & 9 & 4 & 6 & 35 & 1 & 2 & 57 & 5 \\
Asterorotalia & 0 & 25 & 0 & 1 & 0 & 11 & 0 & 37 & 3 \\
Pseudorotalia & 0 & 0 & 54 & 7 & 42 & 16 & 14 & 133 & 11 \\
Bolivina & 0 & 0 & 0 & 0 & 0 & 23 & 20 & 43 & 4 \\
Total & 182 & 158 & 180 & 164 & 177 & 214 & 147 & 1222 & \\
\hline
\end{tabular}




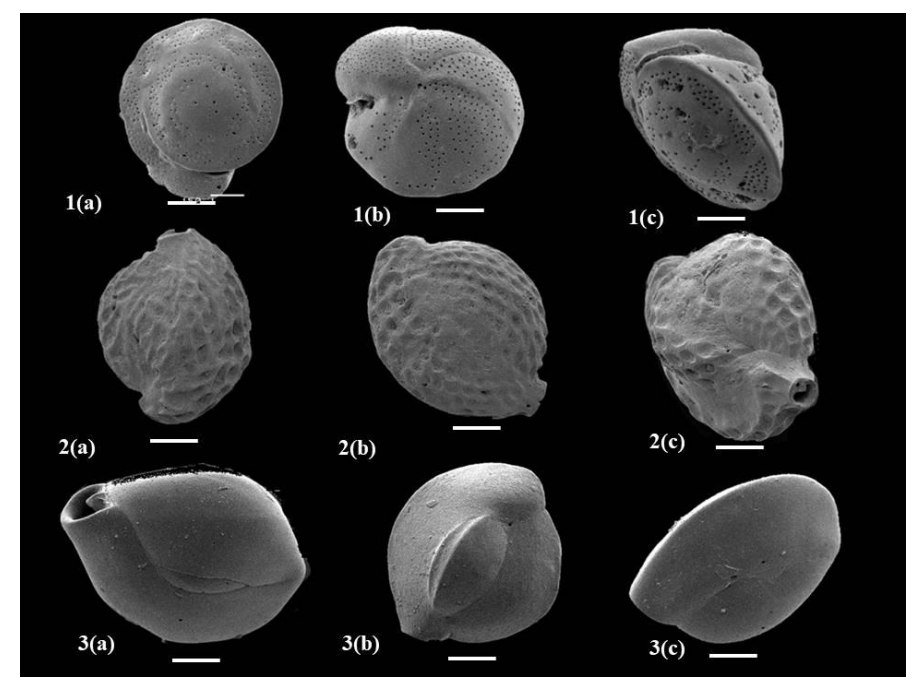

Figure 1: Scanning electron microscope (SEM) images of benthic foraminifera. 1) Heterolepa spp. 1(a) Dorsal

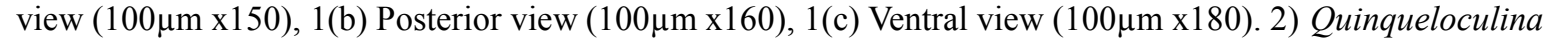

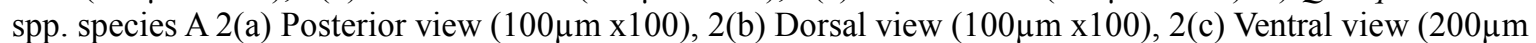

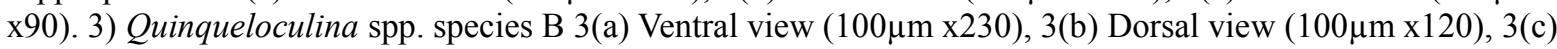
Posterior view $(100 \mu \mathrm{m} \times 220)$.

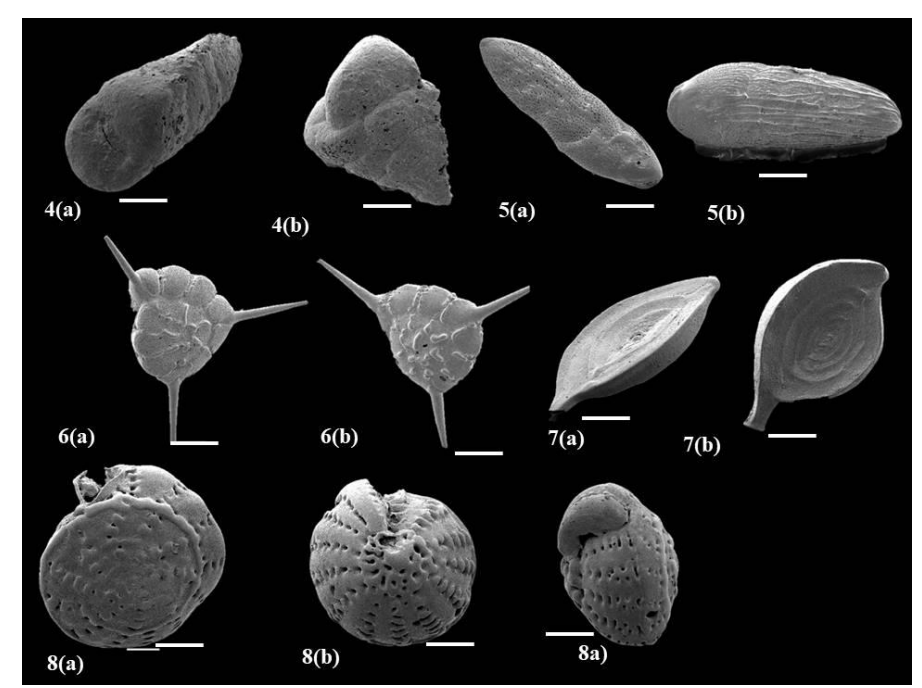

Figure 2: Scanning electron microscope (SEM) images of benthic foraminifera. 4) Textularia spp., 4(a) Ventral

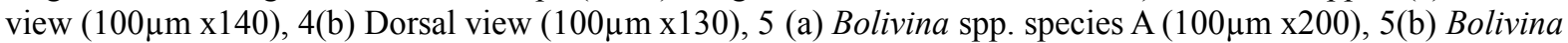

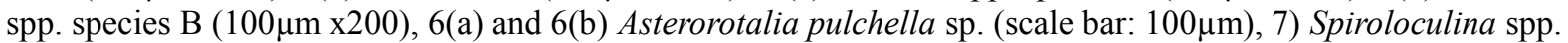

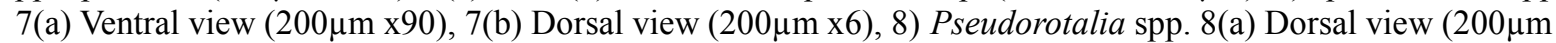

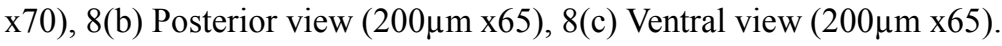

The common ( $>10 \%$ relative abundant) and rare taxa $(<5 \%$ relative abundant) found in seven samples are listed in Table 2. The relative abundance of the five genera that have common genus are Textularia spp.(16\%), Heterolepa spp.(19\%), Operculina spp.(12\%), Quinqueloculina (14\%), Pseudorotalia spp. $(11 \%)$. 
Table 2: Common and rare genus that were found in seven surface samples from northwestern Sarawak's waters.

\begin{tabular}{cccc}
\hline Common Genus & Relative Abundance (\%) & Rare Genus & Relative Abundance (\%) \\
\hline Textularia & 16 & Elphidium & 4 \\
Heterolepa & 19 & Asterorotalia & 3 \\
Operculina & 12 & Bolivina & 4 \\
Quinqueloculina & 14 & & \\
Pseudorotalia & 11 & & \\
\hline
\end{tabular}

\section{Generic Diversity}

Species richness and diversity of benthic foraminifera in northwestern Sarawak's waters are listed in Table 3. The maximum number of genera was found in station $\mathrm{C} 287(\mathrm{~S}=13)$ and the minimum number of genera was found in station $\mathrm{B} 482(\mathrm{~S}=9)$. Station $\mathrm{C} 287$ had the most diverse benthic foraminiferal assemblages $(\alpha=3.23$, $\left.\mathrm{H}^{\prime}=2.30, \mathrm{~d}=2.14\right)$ while the least diverse of benthic foraminiferal was station B482 assemblages $(\alpha=2.0$, $\left.\mathrm{H}^{\prime}=1.90, \mathrm{~d}=1.53\right)$.

Table 3: The genus diversity of benthic foraminifera that were collected in northwestern Sarawak's waters. Number of species(S), species richness (d), Pielou's evenness (J'), Fisher's alpha ( $\alpha)$ and Shannon-wiener (H').

\begin{tabular}{ccccccc}
\hline Station & $\mathrm{S}$ & $\mathrm{N}$ & $\mathrm{d}$ & $\begin{array}{c}\text { Pielou's } \\
\text { evenness(J') }\end{array}$ & $\begin{array}{c}\text { Fisher } \\
\text { alpha }\end{array}$ & $\begin{array}{c}\text { Shannon } \\
\text { wiener } \\
H^{\prime}(\operatorname{loge})\end{array}$ \\
\hline A504 & 9 & 185 & 1.53 & 0.88 & 1.98 & 1.93 \\
A651 & 11 & 177 & 1.93 & 0.86 & 2.60 & 2.06 \\
A674 & 11 & 188 & 1.91 & 0.84 & 2.55 & 2.02 \\
B457 & 12 & 166 & 2.15 & 0.79 & 2.97 & 1.96 \\
B482 & 9 & 189 & 1.53 & 0.87 & 1.97 & 1.91 \\
B469 & 12 & 225 & 2.03 & 0.86 & 2.71 & 2.13 \\
C287 & 13 & 178 & 2.32 & 0.90 & 3.23 & 2.30 \\
\hline
\end{tabular}

\section{Discussion}

There were 11 genera of benthic foraminifera identified from northwestern Sarawak waters. Based on the results, foraminiferal assemblages were mainly dominated by calcareous form. According to Lacuna (2013), the high concentration of $\mathrm{CaCO}_{3}$ in the sediment was due to the presence of appreciable broken gastropod shells and coral fragment. The most abundant genus was Heterolepa spp. (18\%) and followed by Operculina spp. (10\%) and Pseudorotalia spp. (10\%) from calcareous group. The main factor controlling faunal compositions and the distribution of benthic foraminifera was carbon flux (Mackensen et al., 1995; Szarek et al., 2009). The cause of formation of shells benthic foraminiferal may also of the carbon cycle that and the strength of the biological pumping of carbon in the ocean that caused variations of benthic foraminiferal (Lowemark et al., 2005). From the previous study, less than $20 \%$ of the species were commonly occuring along Sunda transect which were Heterolepa spp., Asterorotalia spp.,
Textularia spp. and Triloculina spp. (Szarek et al., 2006) which could also be found in this study area.

The agglutinated foraminiferal found in the samples were Ammobaculites spp. (5\%), Cylindroclavulina spp. (6\%) and Textularia spp. (16\%). The highest number of Textularia spp. was found in sample A504 and B457. Meanwhile, the Cylindroclavulina spp. and Ammobaculites spp. were mostly found in samples A504 and B482. The type of sediment found in Sample A504 was probably medium grained. According to Setty and Nigam (1982), the agglutinated genera and species are dominant in medium grained zones where the organic carbon content varies. Different grain sizes of sediments contain different dominant genus of benthic foraminifera. The distribution pattern of the benthic foraminifera reflects the faunal response to slight varying of environmental conditions such as food supply, water depth, oxygenation, grain size and currents (Srazek et al., 2006). 
The genera that were found in the samples had many different variations. This might be caused by the type of sediment in certain sampling area, which was fine grained sediment. The observation on foraminiferal population and diversity are at its highest in very fine grained sediments (Setty and Nigam, 1982; Lacuna, 2013). Past studies showed that foraminifera are normally common in fine-grained sediment and less abundant coarse sands and with some occurring in silt and clay sediments than in muds (Gooday, 1988; Lacuna, 2013). The South China Sea is one of the basins with the highest diversity of recent benthic foraminiferal faunas in tropical regions (Zheng and Fu, 1994; Srazek, 2009). The sampling site is located in South China Sea which experiences annual monsoon that can disturb current movement and also sediment movement. Since the samples were taken from the surface core, it could possibly affect the distribution and diversity of the benthic foraminiferal. The number of benthic foraminifera species occurring in all the China seas is estimated at approximately 2000, with 1600 species recognized in the assemblages of the entire South China Sea (Zheng and Fu, 1994; Szarek et al., 2006). Both values of Fisher alpha and Shannon-Wiener index from samples taken at northwestern Sarawak waters showed highest values $\left(\alpha=3.23 ; H^{\prime}=2.30\right)$ at station $C 287$. Since the depth of samples was between $43 \mathrm{~m}$ to $71 \mathrm{~m}$, it might influence the diversity of benthic foraminifera in that area. The benthic foraminiferal number and the ShannonWiener index are related to bathymetry and in general, the benthic foraminiferal number is inversely related with water depth (Mendes et al., 2004). Based on Szarek (2009), the middle and lower bathyal depths have a slight increase of diversity and very slight decrease in dominance for living fauna with the value of ShannonWiener index. The diversity index in this study area showed the range between 1.53 and 2.32. Compared to the values of previous studies, the range value of diversity index at Sunda Shelf (South China Sea) was between 3.2 and 4.4 (Szarek et al, 2006). A previous study at Southeast coast of Iligan Bay, Mindanao, Philippines showed the highest value of Fisher alpha at 8.58 and the lowest value at 4.19. According to Szarek (2009), the ratio between agglutinated and calcareous test increased steadily with increasing water depth where the upper bathyal zone composed mainly of calcareous tests while the middle bathyal zone and deeper, the foraminiferal fauna is generally dominated by the agglutinated form. The previous study showed the benthic foraminiferal number was inversely related with water depth (Mendes et al., 2004). However, this study showed the value of the index of diversity did not show any correlation with the depth since the highest value was 2.32 at depth $67.76 \mathrm{~m}$ and the lowest value was 1.53 at depth $45.54 \mathrm{~m}$ and $68.45 \mathrm{~m}$.

\section{Conclusion}

Seven surface sediments from water depth between $43 \mathrm{~m}$ and $71 \mathrm{~m}$ of northwestern Sarawak waters contained eleven genera of benthic foraminifera. The benthic foraminifera can be classified into three groups which are agglutinated, hyaline and porcelanous. The hyaline group which is represented by Heterolepa, Operculina and Pseudorotalia dominated in the assemblages in the study area. Highest diversity index of benthic foraminifera was located at the station C287 with 67.76 $\mathrm{m}$ of depth and the lowest value at station A504 and B482 in northwestern Sarawak waters.

\section{Reference}

A.J. Gooday, Introduction to the Study of Meiofauna, $\mathrm{R}>\mathrm{P}$ Higgins and $\mathrm{H}$. Thiel, Eds. Smithsonian Institution Press, Washington, D.C., 1988.

Buzas, M. A., Collins, L. S., \& Culver, S. J. (2002). Latitudinal difference in biodiversity caused by higher tropical rate of increase. Proceedings of the National Academy of Sciences, 99(12), 7841-7843.

Caromel, A. G., Schmidt, D. N., Phillips, J. C., \& Rayfield, E. J. (2014). Hydrodynamic constraints on the evolution and ecology of planktic foraminifera. Marine Micropaleontology, 106, 6978.

Clarke, K. R., \& Gorley, R. N. (2006). Primer. PrimmerE, Plymouth.

Cosentino, C., Molisso, F., Scopelliti, G., Insinga, D.D., Lubritto, C., Pepe, F., Sacchi, M. (2017). Foraminifera as indicator of relative sea-level fluctuations: Paleoenvironmental and paleoclimatic reconstruction of a Holocene marine succession (Calabria, south-eastern Tyrrhenian Sea). Quaternary International, 439(A), 79-101.

Culver, S. J., Leorri, E., Corbett, D. R., Mallinson, D. J., Shazili, N. A. M., Mohammad, M. N., Parham, P. R., \& Yaacob, R. (2013). Infaunal mangrove swamp foraminifera in the Setiu wetland, Terengganu, Malaysia. Journal of Foraminiferal Research, 43(3), 262-279.

Dambul, R., \& Jones, P. (2007). Regional and temporal climatic classification for Borneo. Geografia: Malaysian Journal of Society and Space, 3(1), 84105.

Debenay, J. P. (2012). A guide to 1,000 foraminifera from Southwestern Pacific: New Caledonia. Marseille (FRA); Paris: Museum, 383p.

Ekman, S. 1953. Zoogeography of the sea. Sidgwick and Jackson. Ltd., London, 417 pp. 
Frezza, V., Bergamin, L., \& Di Bella, L. (2005). Opportunistic benthic foraminifera as indicators of eutrophicated environments. Actualistic study and comparison with the Santernian middle Tiber Valley (Central Italy). Bollentino della Societa Paleontologica Italiana, 44(3), 193-201.

Ganaway, S. M., \& Lacuna, M. L. (2014). Benthic foraminifera in moderately polluted coasts of Iligan City, Philippines: Diversity and abundance. Animal Biology \& Animal Husbandry, 6(1).

Hayward, B. W. (2004). Foraminifera-based estimates of paleobathymetry using Modern Analogue Technique, and the subsidence history of the early Miocene Waitemata Basin. New Zealand Journal of Geology and Geophysics, 47(4), 749-767.

Honjo, S., \& Okada, H. (1968). Scanning Electron Microscopy of Planktonic Foraminifera: A Preparation Technique. Journal of the Faculty of Science, Hokkaido University. Series 4, Geology and mineralogy, 14(1), 71-76.

Iwasaki, S., Kimoto, K., Kuroyanagi, A., \& Kawahata, H. (2017). Horizontal and vertical distributions of planktic foraminifera in the subarctic Pacific. Marine Micropaleontology, 130, 1-14.

Kanamori, H., Yasunari, T., \& Kuraji, K. (2013). Modulation of the diurnal cycle of rainfall associated with the MJO observed by a dense hourly rain gauge network at Sarawak, Borneo. Journal of Climate, 26(13), 4858-4875.

Lacuna, M. L., \& Alviro, M. P. (2014). Diversity and abundance of benthic foraminifera in nearshore sediments of Iligan City, Northern Mindanao, Philippines. Animal Biology \& Animal Husbandry, 6(1).

Lacuna, M. L., Masangcay, S. I., Orbita, M. L., \& Torres, M. A. (2013). Foraminiferal assemblage in Southeast coast of Iligan Bay, Mindanao, Philippines. Aquaculture, Aquarium, Conservation \& Legislation-International Journal of the Bioflux Society (AACL Bioflux), 6(4).

Li, B., Jian, Z., Li, Q., Tian, J., \& Wang, P. (2005). Paleoceanography of the South China Sea since the middle Miocene: evidence from planktonic foraminifera. Marine Micropaleontology, 54(1), 4962.

Löwemark, L., Hong, W. L., Yui, T. F., \& Hung, G. W. (2005). A test of different factors influencing the isotopic signal of planktonic foraminifera in surface sediments from the northern South China Sea. Marine Micropaleontology, 55(1-2), 49-62.
M. B. Cita, M. Zocchi. (1960). Distributionpatterns of Benthic Foraminifera on the floor of the Miditerranian Sea. Oceanological Acta 1978. 1(4). (445-462).

Mendes, I., Gonzalez, R., Dias, J. M. A., Lobo, F., \& Martins, V. (2004). Factors influencing recent benthic foraminifera distribution on the Guadiana shelf (Southwestern Iberia). Marine Micropaleontology, 51(1-2), 171-192.

Mihaljevi, M., Renema, W., Welsh, K., \& Pandolfi, J. M. (2014). Eocene-Miocene shallow-water carbonate platforms and increased habitat diversity in Sarawak, Malaysia. Palaios, 29(7), 378-391.

Minhat, F. I., Satyanarayana, B., Husain, M. L., \& Rajan, V. V. (2016). Modern Benthic Foraminifera in Subtidal Waters of Johor: Implications for Holocene sea-level Change on the East Coast of Peninsular Malaysia. Journal of Foraminiferal Research, 46(4), 347-357.

Murray, JW. (2006). Ecology and applications of benthic foraminifera. New York : Cambridge University Press.

Pawlowski, J., Holzmann, M., Berney, C., Fahrni, J., Gooday, A. J., Cedhagen, T., Habural, A., \& Bowser, S. S. (2003). The evolution of early Foraminifera. Proceedings of the National Academy of Sciences, 100(20), 11494-11498.

Renema, W., (2002). Larger foraminifera as marine environmental indicators. Scripta Geologica. (Vol. 124).

Roberts, C. M., \& Ormond, R. F. (1987). Habitat complexity and coral reef fish diversity and abundance on Red Sea fringing reefs. Marine Ecology Progress Series, 1-8.

Scott, D. B., Medioli, F. S., \& Schafer, C. T. (2001). Monitoring in coastal environments using foraminifera and thecamoebian indicators. Cambridge University Press.

Setty M. G. A. P., Nigam R., 1982 Foraminiferal assemblages and organic carbon relationship in benthic marine ecosystem of western Indian continental shelf. Indian J Mar Sci 11:225-232.

Szarek, R., Kuhnt, W., Kawamura, H., \& Kitazato, H. (2006). Distribution of recent benthic foraminifera on the Sunda Shelf (South China Sea). Marine Micropaleontology, 61(4), 171-195.

Szarek, R., Kuhnt, W., Kawamura, H., \& Nishi, H. 
(2009). Distribution of recent benthic foraminifera along continental slope of the Sunda Shelf (South China Sea). Marine Micropaleontology, 71(1-2), 4159.

Tangang, F. T., Juneng, L., \& Ahmad, S. (2007). Trend and interannual variability of temperature in Malaysia: 1961-2002. Theoretical and Applied Climatology, 89(3-4), 127-141.

Wilson, M. E., \& Rosen, B. R. (1998). Implications of paucity of corals in the Paleogene of SE Asia: plate tectonics or centre of origin. Biogeography and geological evolution of SE Asia, 165-195.

Yahya, K., Shuib, S., Minhat, F. I., Ahmad, O., \& Talib, A. (2014). The distribution of benthic foraminiferal assemblages in the north-west coastal region of Malacca Straits, Malaysia. Journal of Coastal Life Medicine, 2(10), 784-790.

Zheng, S.-Y., Fu, Z.-X., 1994. Foraminiferal faunal trends in China Seas. In: Zhou, D. (Ed.), Oceanology of China Seas. Kluwer Academic Publishers, Dordrecht, pp. 255-274. 